4. Canadian Broadcasting Corporation. Worst case scenario. The CBC Digital Archives Website [Video]. November 12, 2004. Available at: http://archives.cbc.ca/environment/ natural_disasters/clips/9936/. Accessed March 8, 2010.

5. Waeckerle JF. Disaster planning and response. N Engl J Med. 1991;324:815-821.

6. Arnold T, Cleary V, Groth S, Hook R, Jones D, Super G. START. Newport Beach, CA: Newport Beach Fire and Marine Department; 1994.

7. Kennedy K, Aghababian RV, Gans L, Lewis CP. Triage: techniques and applications in decision making. Ann Emerg Med. 1996;28:136-144.

8. Hodgetts T, Porter C, eds. Major Incident Medical Management and Support: The Practical Approach. 2nd ed. London: BMJ Publishing Group; 2002.

9. Mackersie RC. Field triage, and the fragile supply of "optimal resources" for the care of the injured patient. Prehosp Emerg Care. 2006;10:347-350.

10. Kahn CA, Lerner EB, Cone DC. Triage. In: Koenig KL, Schultz CH, eds. Koenig and Schultz's Disaster Medicine: Comprehensive Principles and Practices. New York: Cambridge University Press; 2010:174-183.

11. Sasser S. Field triage in disasters. Prehosp Emerg Care. 2006;10:322-323.

12. Oberhammer R, Beikircher W, Hormann C, et al. Full recovery of an avalanche victim with profound hypothermia and prolonged cardiac arrest treated by extracorporeal re-warming. Resuscitation. 2008;76: $474-480$.

13. Brugger H, Durrer B, Adler-Kastner L, Falk M, Tschirky F. Field management of avalanche victims. Resuscitation. Oct 2001;51:7-15.

14. Boyd J, Brugger H. For avalanche victims in cardiac arrest (P), what factors when present (I), compared with when absent $(\mathrm{C})$, are associated with/predict an increased survival to hospital discharge (O)? Advanced Life Support Worksheets-Special Circumstances. Dallas, TX: International Liaison Committee on Resuscitation 2010. Available at: http:// www.americanheart.org/presenter.jhtml?identifier $=3065168$. Accessed March 8, 2010.

15. Boyd J, Brugger H, Shuster M. Prognostic factors in avalanche resuscitation: a systematic review. Resuscitation. In press.

16. Hohlrieder M, Thaler S, Wuertl W, et al. Rescue missions for totally buried avalanche victims: conclusions from 12 years of experience. High Altitude Medicine and Biology. 2008;9:229-233.

17. Hohlrieder M, Mair P, Wuertl W, Brugger H. The impact of avalanche transceivers on mortality from avalanche accidents. High Alt Med Biol. 2005;6:72-77.

18. Brugger H, Etter HJ, Zweifel B, et al. The impact of avalanche rescue devices on survival. Resuscitation. 2007; 75:476-483.

19. Brugger H. Should strategies for care of avalanche victims change? CMAJ. 2009;180:491-492.

\section{Physiological Demands of Hiking the Grand Canyon}

To the Editor:

Hiking from top to bottom of the Grand Canyon National Park in Arizona has been a popular endeavor for many years. The most common hike starts at approximately $2100 \mathrm{~m}$ above sea level and follows the South Kaibab Trail to Phantom Ranch at the bottom of the canyon (732 $\mathrm{m}$ above sea level) and back. The length $(\sim 30 \mathrm{~km})$, duration (6-9 hours), and inclination $(\sim 13 \%)$ of this journey exerts extraordinary strain on the hikers' physique, which is influenced by dietary intake, backpack weight, and environmental conditions. The ambient temperatures at the canyon vary widely throughout the year, exceeding $38^{\circ} \mathrm{C}\left(100.4^{\circ} \mathrm{F}\right)$ in the summer months and falling below $-18^{\circ} \mathrm{C}\left(-0.4^{\circ} \mathrm{F}\right)$ during the winter. ${ }^{1}$ To prevent the risk of dehydration, heat stroke, hyperthermia, and hypoglycemia, especially in unacclimatized and inexperienced hikers, the Park Service does not recommend completing this journey in 1 day, as evidenced by numerous warning signs.

The intent of this letter is to highlight potential areas of further research regarding the physiological responses to desert hiking and severe environmental conditions. To carefully estimate the cardiopulmonary and metabolic demands during hiking in such an environment, 1 male (age: 31 years, weight: $77.2 \mathrm{~kg}$, height: $179.0 \mathrm{~cm}$ ) volunteered for a trial, following 5 days of acclimatization to the altitude. The hiker's peak oxygen uptake $\left(\mathrm{VO}_{2 \text { peak }}\right)$ of $61.2 \mathrm{~mL} \cdot \mathrm{min}^{-1} \cdot \mathrm{kg}^{-1}$ and maximal heart rate $\left(\mathrm{HR}_{\max }\right)$ of $191.0 \mathrm{bpm}$ were measured during a treadmill ramp protocol (Woodway, Lörrach, Germany; starting at 12 $\mathrm{km} \cdot \mathrm{h}-1$ and increasing $1^{\circ} \cdot \mathrm{min}^{-1}$ ) using a breath-bybreath analyzer (Metamax 3B, Leipzig, Germany) 10 days before the journey.

Accompanied by a research team, the volunteer hiker started from Yaki Point on the South Rim at 7:45 AM on March 21, 2009. The descent via the South Kaibab Trail lasted 3:15 hours and led to Phantom Ranch ( $\sim 13 \%$ mean grade), the reversal point of the hike. The uphill hike followed the Bright Angel trail ( $\sim 13 \%$ mean grade) and lasted approximately 4 hours. The volunteer was instructed to hike at a self-selected constant pace.

The ambient temperature during the day ranged from $15^{\circ} \mathrm{C}$ in the morning up to $29^{\circ} \mathrm{C}$ at $1: 48 \mathrm{PM}$. The volunteer wore shorts and a light wind jacket during the first hour of the hike, thereafter he switched to shorts and T-shirt. Oxygen uptake $\left(\mathrm{VO}_{2}\right)$, respiratory exchange ratio (RER), and heart rate (HR; Polar Belt, Kempele, Finland) were collected telemetrically throughout the entire hike (Metamax 3B). Based on these data, the active energy expenditure (AEE) of the participant was calcu- 


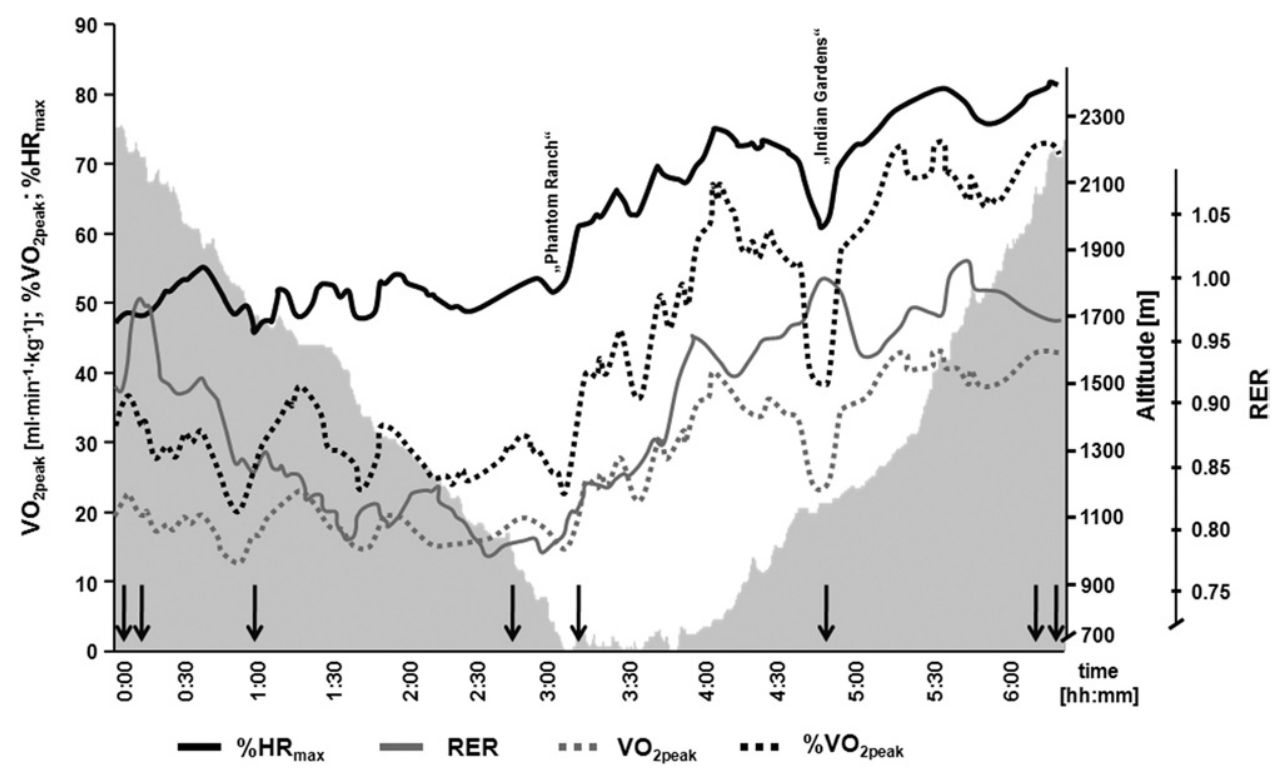

Figure. Subject's relative oxygen uptake kinetics (dotted grey), percent of $\mathrm{VO}_{2 \text { peak }}$ (dotted black), percent of maximum HR (black), and RER (grey) over time according to the altitude profile. Black arrows above the time scale indicate short breaks for collecting Lac and Gluc.

lated according to previously published data. ${ }^{2,3}$ The total weight of the gear was $4.5 \mathrm{~kg}$, including backpack and breath-by-breath analyzer. Samples $(20 \mu \mathrm{L})$ of capillary blood for the measurement of lactate (Lac) and glucose (Gluc) concentration (Eppendorf EBIO Plus, Hamburg, Germany) were taken during short breaks (see Figure for time points).

\section{Downhill Section}

According to $\mathrm{HR}, \mathrm{VO}_{2}$, Lac, Gluc, and AEE, the findings revealed low cardiorespiratory and metabolic demands during the downhill section. $\mathrm{HR}$ and $\mathrm{VO}_{2}$ remained constant and did not exceed $40 \%$ and $60 \%$ of the individual's maximum, reflecting light to moderate exercise, according to the American College of Sports Medicine Position Statement. ${ }^{4}$ Lac values remained below 2.0 $\mathrm{mmol} \cdot \mathrm{L}^{-1}$ and RER decreased from 0.95 to 0.97 at the start to approximately 0.80 at the bottom, indicating that fat oxidation was the major source of energy during this part of the hike. ${ }^{5}$ There was no indication of hypoglycemia during this period, with Gluc in a stable range of 72 to $96 \mathrm{mg} \cdot \mathrm{dL}^{-1}$.

\section{Uphill Section}

In general, the uphill part of the hike showed increasing cardiorespiratory values that peaked towards the end. Oxygen uptake and HR reached $75 \%$ to $80 \%$ of the individual's $\mathrm{VO}_{2 \text { peak }}$ and $\mathrm{HR}_{\text {max }}$ (see Figure). In comparison, similar peak values have been reported in a $160-\mathrm{km}$ backpacking trip, ${ }^{6}$ as well as during marathon racing $(75 \%-85 \%),{ }^{7,8}$ highlighting the exertion of this hike. Also, the Lac concentration of $3.7 \mathrm{mmol} \cdot \mathrm{L}^{-1}$ at the end of the hike confirms an increased amount of anaerobic contribution to energy production. Especially during the last 2 hours of the hike near the top of the rim, RER values increased to 1.05 to 1.10 , indicating that carbohydrates (CHO) were the major source of energy.

Close to Indian Gardens (a common resting point to collect water), Gluc levels declined from $138 \mathrm{mg} \cdot \mathrm{dL}^{-1}$ to $58 \mathrm{mg} \cdot \mathrm{dL}^{-1}$, indicating a hypoglycemic state. Food supply (Cliff Bar and 1.0 L of Gatorade) normalized the level of blood Gluc $\left(96 \mathrm{mg} \cdot \mathrm{dL}^{-1}\right)$. The calculation of energy intake and energy expenditure at the end showed an energy deficit of $1226 \mathrm{kcal}$. This was due to an accumulated active energy expenditure of $3322 \mathrm{kcal}$, while the accumulated energy intake was $2096 \mathrm{kcal}$ during the hike. This deficit demonstrates the need for proper caloric and fluid intake strategies to prevent harmful effects, such as hypoglycemia and compromised physical function. Nevertheless, despite the physical strain and the negative energy balance, blood Gluc levels were maintained as long as $\mathrm{CHO}$ were ingested.

\section{Conclusion}

Even though our volunteer could be classified as well trained and experienced in hiking, he developed hypoglycemia, reflecting the necessity for proper nutrition and hydration. From a physiological point of view, the profile of the hike exerts high demands on the cardiopulmonary 
and metabolic system and should not be recommended for physically untrained persons, especially during hot conditions. Despite the fact that this case only investigated 1 volunteer and 1 hike, this letter may help to highlight further research needs regarding the responses to desert hiking. These include: (1) nutrition; (2) clothing and equipment; and (3) physical fitness preparation for desert hiking.

\section{Billy Sperlich, $\mathrm{PhD}$ \\ Matthias Haegele \\ Marcus de Marées, MD \\ Joachim Mester, $\mathrm{PhD}$ \\ Cologne, Germany \\ John Linville, MPH, CPH \\ Omaha, NE, USA}

\section{References}

1. National Park Service. http://www.nps.gov/grca/ planyourvisit/backcountry.htm Accessed: September 2009.

2. Weir JB. New methods for calculating metabolic rate with special reference to protein metabolism. J Physiol. 1949; 109:1-9.

3. Cunningham JJ. Body composition as a determinant of energy expenditure: a synthetic review and a proposed general prediction equation. Am J Clin Nutr. 1991;54:963-969.

4. American College of Sports Medicine Position Stand. The recommended quantity and quality of exercise for developing and maintaining cardiorespiratory and muscular fitness, and flexibility in healthy adults. Med Sci Sports Exerc. 1998;30:975-991.

5. Brooks GA, Mercier J. Balance of carbohydrate and lipid utilization during exercise: the "crossover" concept. $J$ Appl Physiol. 1994;76:2253-2261.

6. Burtscher M, Bachmann O, Hatzl T, et al. Cardiopulmonary and metabolic responses in healthy elderly humans during a 1-week hiking programme at high altitude. Eur J Appl Physiol. 2001;84:379-386.

7. Bassett DR Jr, Howley ET. Limiting factors for maximum oxygen uptake and determinants of endurance performance. Med Sci Sports Exerc. 2000;32:70-84.

8. Costill DL, Winrow E. Maximal oxygen intake among marathon runners. Arch Phys Med Rehabil. 1970;51:317-320.

\section{Medicinal Alcohol for Exercise-Associated Hyponatremia?}

\section{To the Editor:}

I read with interest the article by Rogers and Hew-Butler concerning exercise-associated hyponatremia. ${ }^{1}$ While one might dispute whether it constitutes "the most important medical problem of endurance exercise," exercise-associated hyponatremia clearly presents a serious diagnostic and treatment challenge, particularly in the wilderness environment. Front-line treatment consists of hypertonic saline infusion, yet this may not be readily available or easily administered in all field conditions. Similar limitations apply to the monitoring of serum sodium deemed necessary to manage this treatment. ${ }^{1,2}$ Also, hypertonic saline administration carries risk of complications nearly as severe as hyponatremia. ${ }^{2}$

These authors and others ${ }^{1-3}$ note that inappropriately excessive arginine vasopressin (AVP, also known as antidiuretic hormone or ADH) secretion contributes significantly to the pathophysiology of exercise-induced hyponatremia by limiting aquaresis. Alcohol (ethanol) is a well-established and potent inhibitor of AVP secretion, and circulating AVP is rapidly catabolized. ${ }^{4,5}$ Therefore, I write primarily to hypothesize that oral ethanol consumption may provide a hyponatremia treatment alternative worth investigation. Due to the necessity of limiting water intake with hyponatremia, hard liquor ( $\sim 40 \%$ ethanol) offers the most medically logical mode of administration. A moderate dose may prove effective $(0.5 \mathrm{~mL}$ ethanol per kg body weight, or about 2-3 shots of 80 proof liquor), yet only research confirms such matters. The need for sodium intake suggests tequila shots with the customary salt and citrus. The idea offers several advantages: hard liquor is often brought along for recreational purposes even in remote situations, oral consumption requires no intravenous line, moderate oral ethanol imposes no risks comparable to those of intravenous hypertonic saline, and serum sodium monitoring to avoid overcorrection of hyponatremia becomes much less important.

As long as it is not overzealous, ethanol consumption may deserve investigation as a treatment alternative for exercise-associated hyponatremia.

\section{Donald E. Watenpaugh, $\mathrm{PhD}$ University of North Texas Health Science Center Fort Worth, TX, USA}

\section{References}

1. Rogers IR, Hew-Butler T. Exercise-associated hyponatremia: overzealous fluid consumption. Wilderness Environ Med. 2009;20:139-143.

2. Sterns RH, Nigwekar SU, Hix JK. The treatment of hyponatremia. Semin Nephrol. 2009;29:282-299.

3. Rosner MH. Exercise-associated hyponatremia. Semin Nephrol 2009;29:271-281.

4. Kalant H. Direct effects of ethanol on the nervous system. Fed Proc. 1975;34:1930-1941.

5. Wright J. Endocrine effects of alcohol. Clin Endocrinol Metab. 1978;7:351-367. 